\title{
The impact of attitude strength on the use of customer satisfaction information: an empirical investigation
}

Citation for published version (APA):

van Birgelen, M. J. H., de Ruyter, J. C., \& Wetzels, M. G. M. (2000). The impact of attitude strength on the use of customer satisfaction information: an empirical investigation. METEOR, Maastricht University School of Business and Economics. METEOR Research Memorandum No. 037 https://doi.org/10.26481/umamet.2000037

Document status and date:

Published: 01/01/2000

DOI:

10.26481/umamet.2000037

Document Version:

Publisher's PDF, also known as Version of record

\section{Please check the document version of this publication:}

- A submitted manuscript is the version of the article upon submission and before peer-review. There can be important differences between the submitted version and the official published version of record.

People interested in the research are advised to contact the author for the final version of the publication, or visit the DOI to the publisher's website.

- The final author version and the galley proof are versions of the publication after peer review.

- The final published version features the final layout of the paper including the volume, issue and page numbers.

Link to publication

\footnotetext{
General rights Owners
rights.

- You may freely distribute the URL identifying the publication in the public portal. please follow below link for the End User Agreement:

www.umlib.nl/taverne-license

Take down policy

If you believe that this document breaches copyright please contact us at:

repository@maastrichtuniversity.nl

providing details and we will investigate your claim.
}

Copyright and moral rights for the publications made accessible in the public portal are retained by the authors and/or other copyright owners and it is a condition of accessing publications that users recognise and abide by the legal requirements associated with these

- Users may download and print one copy of any publication from the public portal for the purpose of private study or research.

- You may not further distribute the material or use it for any profit-making activity or commercial gain

If the publication is distributed under the terms of Article $25 \mathrm{fa}$ of the Dutch Copyright Act, indicated by the "Taverne" license above, 


\title{
The Impact of Attitude Strength on the Use of Customer Satisfaction Information: An Empirical Investigation
}

\author{
Marcel van Birgelen \\ Ko de Ruyter \\ Martin Wetzels
}

MAXX WORKING PAPER SERIES

Maastricht Academic Center
for research in Services 


\title{
The impact of attitude strength on the use of customer satisfaction information: An empirical investigation
}

\begin{abstract}
Considering the strategic importance of satisfying customers and the high costs of conducting customer satisfaction research, deeper understanding of the determinants of customer satisfaction information use seems important. In this paper, we aim at predicting intentions of selectively using satisfaction-related information from decision-maker attitude strength by applying latent variable modelling. The results suggest that two dimensions of attitude strength, commitment and embeddedness, contribute directly and indirectly to selective customer satisfaction intelligence use. Indirect effects occur through cognitive processes and selective judgment of satisfaction-related information.
\end{abstract}




\section{Introduction}

Organizations place great emphasis on satisfying their customers nowadays. A recent quote from a well-known fortune 500 company's mission statement illustrates this: "At Motorola Customer Satisfaction is our top priority". An emerging body of academic investigations has established the economic benefits of customer satisfaction empirically (e.g., Anderson, 1996; Rust et al., 1995; Wetzels et al., 1998). These include customer retention, customer commitment, positive word of mouth, and higher profitability.

As a consequence, organizations search for ways to monitor their customers' satisfaction levels and collect information on the "customer voice". Considerable portions of marketing budgets are often spent on conducting customer satisfaction surveys. However, it has been argued that competitive advantage does not lie in access to intelligence but in the ability to effectively use it (Menon and Varadarajan, 1992; Moorman et al., 1992). In the modern context of tremendous information availability through advances in information technology and research practice, use of customer satisfaction-related information does not always appear to be optimal. Decision-makers get frustrated when it turns out that, despite of repeated measurement and attention for quality-related issues, no changes in customer satisfaction levels are evident (Mulder, 1999). This could cause managers to cast doubt on the topic of customer satisfaction. Moreover, customer satisfaction research is often conducted on behalf of managers who have a marketing (research) background and who occupy positions in which customer orientation is pivotal. Hence, they have often developed relatively strong views on how this type of research should be conducted (Deshpandé and Zaltman, 1982). This could easily lead to mistrust in, selective use, or non-use of information.

Given the economic cost of customer satisfaction research and the tremendous opportunity cost of not using information, it seems worthwhile to further develop our understanding of 
determinants of customer satisfaction intelligence use. Over the years, marketing intelligence utilization has received substantial attention in academic and managerial literature (e.g., Deshpandé and Zaltman, 1982, 1984, 1987; Lee et al., 1987; Maltz and Kohli, 1996; Moorman et al., 1992, 1993; Raphael and Parket, 1991). The majority of this literature explains significant variance in marketing information use with external factors, such as research quality, actionability and acceptability of results, interpersonal characteristics of the researcher, and organizational characteristics. However, with the exception of a few studies (e.g., Lee et al., 1987, 1997; Perkins and Rao, 1990), little research efforts have contributed to internal, decision-maker-related factors and of these studies none focused explicitly on customer satisfaction-related information.

Based on findings in social and organizational psychology and behavioural decision-making research, we posit that internal dispositions about customer satisfaction can be expected to codetermine intelligence use. Strong evidence was found for the effect of attitude strength on behaviour and behavioural intentions (see Krosnick and Petty (1995) for an overview). In addition to a strongly held position, we argue that mediating factors, such as cognitive elaboration on customer satisfaction and selective judgment of information, will impact the use of information. The paper is structured as follows. First, a review will be given of attitude strength in order to develop a more profound understanding of this theoretical concept. Next, cognitive and behavioural implications of attitude strength will be introduced. This background review will then serve to develop a conceptual framework on the consequences of attitude strength for intentions of using satisfaction-related information. After presenting the results of an empirical study the paper will conclude with a discussion of several theoretical and managerial implications. 


\section{Attitude strength: An overview}

Individuals tend to differ in the way they relate to specific issues. In the social and economic psychology literature, among others, the term attitude is used to describe these differences. A basic definition of an attitude is: "Attitude is a psychological tendency that is expressed by evaluating a particular entity with some degree of favor or disfavor" (Eagly and Chaiken, 1993, p. 1). Attitudes can differ in strength between persons. Attitude strength, a concept frequently used in attitude research and theory (Pomerantz et al., 1995), is traditionally studied in settings of socially significant and controversial issues (e.g., Krosnick et al., 1993).

A review of the literature fails to give a predominating conceptual definition of this concept. Nonetheless, an overall consensus can be found: strong attitudes are described as resulting in selective cognitive processing and will be resistant to change, persistent over time, and highly predictive of behaviour (Abelson, 1988; Chaiken et al., 1995; Eagly and Chaiken, 1993, 1995; Krosnick et al., 1993; Olson and Zanna, 1993). Krosnick and Petty (1995) also refer to the strong impact of attitude strength on behaviour and the processing of information. In our perspective, both characteristics of attitude strength, its impact on behaviour and information processing, contribute strongly to the relevancy of this concept for a study on intentions to use customer satisfaction-related information.

There are several questions surrounding the concept of attitude strength. One major issue focuses on whether it consists of one single construct or several. Constructs used to define attitude strength vary from one study to another. They are often highly correlated or even assumed to be completely interchangeable. Good reviews exist of explorative studies on attitude strength constructs, their correlation, and their interchangeability (i.e. Abelson, 1988; Krosnick et al., 1993; Raden, 1985). The main tenet is that several studies have moved away from considering attitude strength as one single construct toward operationalising it into 
several underlying constructs (Abelson, 1988; Krosnick et al., 1993; Lastovika and Gardner, 1979; Raden, 1985).

For three different samples and five distinct issues, Pomerantz et al. (1995) found an identical factor structure indicating the existence of two dimensions underlying attitude strength. These factors were highly similar to factor solutions found in other studies (e.g., Abelson, 1988; Lastovika and Gardner, 1979). The first factor is referred to as commitment and the second as embeddedness. Commitment can be described as the degree to which one feels secure and positive that one's opinion concerning a certain entity is correct and one takes a strong position in defending that belief. Embeddedness, on the other hand, indicates how one is personally attached and involved with an issue, and the belief that one's attitude position reflects an inner self-value. Given their success in predicting behaviour and their resemblance with constructs found in earlier research, we confidently adopt embeddedness and commitment to conceptualise attitude strength.

Exploratory factor analyses revealed that attitude commitment was operationalised by items relating to attitude certainty as well as extremity of one's attitude position toward an issue (Pomerantz et al., 1995). Both characteristics are well established within the economic psychology and marketing literature (e.g., Davidson et al., 1985; Marks and Kamins, 1988; Van der Pligt et al., 1983). Certainty can be defined as "...the degree to which an individual is confident that his or her attitude toward an object is correct..." (Krosnick et al., 1993, p. 1132). Extremity relates to "...the extent to which an individual's attitude deviates from the midpoint of the favorable-unfavorable dimension..." (Krosnick et al., 1993, p. 1132).

Embeddedness was shown to be related to personal importance, ego involvement, and knowledgeability concerning some entity (Pomerantz et al., 1995). These characteristics also have a considerable foundation in academic literature (e.g., Jaccard and Becker, 1985; Krosnick, 1988, 1990; Wood and Kallgren, 1988). Personal importance is defined as “...the 
extent to which an individual cares deeply about and is personally invested in an attitude..." (Krosnick et al., 1993, p. 1132). According to Pomerantz et al. (1995) ego involvement measures the centrality of one's attitude to the self-concept and value system. Finally, Krosnick et al. (1993, p. 1133) refer to knowledgeability as “...the amount of information about an object that accompanies one's attitude toward it in memory...". An overview of attitude strength and the constructs underlying it remains of little use for an empirical study on customer satisfaction-related information use without identifying relevant consequences. Therefore, the next section will elaborate on the cognitive and behavioural implications of attitude strength.

\section{Attitude strength: Cognitive and behavioural consequences}

Various studies have shown that stronger attitudes contribute to (the likelihood of) behaviour (e.g., Jaccard, 1981; Jaccard and Becker, 1985; Pomerantz et al., 1995). This is exemplified by Krosnick and Petty (1995, p. 3) who state that "Attitudes can guide behaviour, and strong attitudes should be more likely to do so than weak ones". Fishbein and Ajzen (1975) developed the attitude-behaviour relationship with their theory of reasoned action. The theory proposes that actual behaviour is determined by an intention to engage in that behaviour. In turn, this intention is determined by a subject's attitude toward the behaviour and environmental subjective norms concerning that behaviour. As will become clear, we also adopt the basic ideas of the theory of reasoned action for the development of our conceptual framework. More specifically, it is expected that stronger attitudes concerning customer satisfaction will elicit intentions to engage in attitude-congruent behaviour, which will be the selective use of satisfaction-related intelligence. The intentions will then function as predictors of actual behaviour. 
According to Pomerantz et al. (1995), with regards to the behavioural implications of attitude strength, a distinction must be made between mediating selective cognitive processes and resistance outcomes. As stated by Krosnick and Petty (1995, p. 3) “...attitudes can influence information processing and judgments". Therefore, attitude strength can directly influence (intentions of) behaviour but can also have an indirect effect via selective cognitive processes, which in turn lead to resistance to change and attitude-incongruent positions (Eagly and Chaiken, 1995). In attitude strength research, several of cognitive processes have been identified, such as selective exposure, selective attention, selective cognitive elaboration, selective perception, and selective memory (Eagly and Chaiken, 1993). In turn, Pomerantz et al. (1995) use selective judgment and attitude polarization measurements for assessing resistance outcomes and both issues have been the focus of numerous other studies as well (Eagly and Chaiken, 1993; Fiske and Taylor, 1991; Lord et al., 1979; Sherman et al., 1989).

The basic ideas of selective cognitive processes and resistance outcomes are important for understanding the effect of attitude strength on selective use of customer satisfaction-related information. The potential of attitude strength as a concept predicting selective use of satisfaction-related information emanates from these underlying processes. Besides in stronger intentions to act strong attitudes can be expected to result in more elaborate cognitive processes concerning the attitude entity. By thinking more elaborately about it one tends to selectively judge or evaluate information dealing with the entity on the basis of a normative framework that has been developed concerning the entity. Lee et al. (1987) refer to this phenomenon as 'belief perseverance', which they base their finding on that research confirming prior beliefs tends to be rated higher and is more likely to be used. On the basis of the previous discussion, we now will develop a conceptual framework on the effects of attitude strength concerning customer satisfaction on marketing decision-maker intentions to selectively use satisfaction-related information. 


\section{Conceptual framework and research hypotheses}

Based on Pomerantz et al. (1995), we consider attitude strength to be a two-dimensional concept encompassing commitment and embeddedness. Our objective is to empirically test the relationship between decision-maker attitude strength concerning the importance of customer satisfaction and intentions to selectively use customer satisfaction-related marketing intelligence. On the basis of the previous literature review, we expect this relationship to be direct but also to be mediated by other factors.

Following from its general conceptualisation, attitude commitment refers to feeling secure and positive that one's attitude concerning the importance of customer satisfaction is correct and to taking a strong position in defending this belief. We expect that commitment will increase the level to which one cognitively elaborates upon issues relating to customer satisfaction, for example on the positive consequences of satisfying customers for an organization. For important decisions individuals tend to reflect more on the matter (Jaccard et al., 1995). Furthermore, several strength variables were found to increase selective cognitive elaboration (Chaiken et al., 1995; Chaiken and Yates, 1985). More specifically, Pomerantz et al. (1995) found empirical evidence for a positive association between attitude commitment toward an issue and selective cognitive elaboration.

$H_{1}$ : $\quad$ There will be a positive relationship between commitment toward the importance of customer satisfaction and cognitive elaboration on customer satisfaction.

In the literature there is little research explicitly examining the relationship between attitude strength and selective judgment (Chaiken et al., 1995; Houston and Fazio, 1989; Miller et al., 1993). However, Pomerantz et al. (1995) concluded that the level of commitment toward an 
issue had a positive effect on selective judgment of issue-related information. Therefore, we expect that decision-maker commitment toward customer satisfaction will contribute to the selective judgment of satisfaction-related information. This judgment is based on an attitudecongruent normative framework used to evaluate the information.

$\mathrm{H}_{2}$ : $\quad$ There will be a positive relationship between commitment toward the importance of customer satisfaction and selective judgment of customer satisfaction-related information.

Next, decision-makers committed to customer satisfaction are likely to show higher intentions to act in accordance with this attitude. More specifically, they will display higher intentions to use information, supporting their attitude that customer satisfaction is important for the organization. As mentioned, the positive attitude-behaviour relationship has been supported by various other studies (e.g., Jaccard, 1981; Jaccard and Becker, 1985; Pomerantz et al., 1995). Pomerantz et al. (1995) showed that attitude commitment positively influences intentions to act in accordance with this attitude.

$H_{3}$ : $\quad$ There will be a positive relationship between commitment toward the importance of customer satisfaction and intentions to selectively use customer satisfaction-related information.

The effects of attitude embeddedness on cognitive elaboration have been well documented in psychological literature as well as in marketing settings. Petty and Cacioppo (1979) showed that issue involvement and personal relevance (similar to what Pomerantz et al. (1995) refer to as ego involvement and personal importance) increase one's motivation to process 
information. Since then the relationship between issue involvement and processing effort has received considerable attention and been confirmed in various other studies as well (e.g., Beatty and Smith, 1987; Chaiken, 1980; Greenwald and Leavitt, 1984; Maheswaran and Myers-Levy, 1990; Petty and Cacioppo, 1986a, 1986b; Petty et al., 1983). Furthermore, prior knowledge has also been shown to positively influence information processing (Maheswaran and Sternthal, 1990). This leads us to expect that embeddedness of the importance of customer satisfaction will increase decision-maker cognitive elaboration on customer satisfaction.

$H_{4}$ : $\quad$ There will be a positive relationship between embeddedness of the importance of customer satisfaction and cognitive elaboration on customer satisfaction.

Similar to attitude commitment, we expect that embeddedness will also contribute to decisionmaker selective judgment. Decision-makers in whom the importance of customer satisfaction is strongly embedded are more likely to selectively judge customer satisfaction-related information against a normative framework.

$H_{5}$ : $\quad$ There will be a positive relationship between embeddedness of the importance of customer satisfaction and selective judgment of customer satisfaction-related information.

In decision-making experiments it has been shown that prior knowledge, underlying embeddedness, influences behaviour of information acquisition and use (Lee et al., 1999). Following Pomerantz et al. (1995) we posit that embeddedness of the importance of customer satisfaction will directly result in higher intentions of selectively using satisfaction-related 
information. Information that is in accordance with this attitude is more likely to be used for decision-making purposes than information that does not conform to this attitude (e.g., information not underlining the importance of satisfying customers).

$H_{6}$ : There will be a positive relationship between embeddedness of the importance of customer satisfaction and intentions to selectively use customer satisfaction-related information.

Selective cognitive elaboration on a specific issue strongly increases the level of selective judgment of information concerning this issue (Pomerantz et al., 1995). As a consequence, we expect that decision-makers who cognitively elaborate on customer satisfaction and its importance for the organization ('who feel they know what they are talking about and dealing with') are more likely to judge/evaluate customer satisfaction-related information on the basis of an attitude-congruent normative framework. The respective hypothesis is as follows:

$H_{7}$ : There will be a positive relationship between cognitive elaboration on customer satisfaction and selective judgment of customer satisfaction-related information.

Finally, decision-makers who selectively judge customer satisfaction-related information on the basis of their personal attitude or belief are likely to act in accordance with this belief. Based on Hogarth and Makridakis (1988), we expect that they are more likely to express intentions of using information that underlines the importance of satisfying customers for the success of organizational activities: 
$H_{8}$ : There will be a positive relationship between selective judgment of customer satisfaction-related information and intentions to selectively use customer satisfactionrelated information.

The hypotheses we formulated above can be summarized by the conceptual model presented in fig. 1.

[Insert Fig. 1 about here]

The next section will elaborate on an empirical study conducted to test our theoretical framework on customer satisfaction attitude strength.

\section{An empirical study}

\subsection{Research design and data collection}

The empirical study for testing our hypotheses was conducted among decision-makers of a multinational office equipment manufacturer. A service research center in the Netherlands has been conducting a large-scale international customer satisfaction survey in several countries focusing on after-sales services, such as product delivery, installation, customer support, service visits, and complaint handling. Respondents were required to be in marketing decision-making positions in which they would come into contact with the customer satisfaction-related information produced by the research project. Respondents were selected on the basis of their job titles for which descriptions were made available by the 
organization's management. Job titles of actual respondents varied from product managers to senior marketing executives.

Questionnaires were distributed personally by thoroughly instructed students who were active as interns in the organization. This procedure allowed us to exercise a certain level of control over the composition of the sample in terms of validity and the final response rate. In total, 174 questionnaires were handed out. Ultimately, the response totalled 121 respondents meeting the required criteria. This represents a response rate of $70 \%$, which is likely to be that high due to the personal approach in the sampling procedure.

\subsection{Questionnaire development}

The questionnaire was developed by reviewing the measurement instruments of attitude strength and related constructs in previous research. The items were adapted to the current marketing decision-making situation focusing on customer satisfaction and its importance to the organization. The questionnaire was extensively pre-tested and refined prior to actual data collection by administering it to several subjects from the target population who in in-depth interviews commented on potential misunderstandings and misconceptions. In order to avoid test-retest biases subjects involved in the pre-testing of the questionnaire were not included in the final sample. On the basis of the pre-test several items were adapted before including them in the final questionnaire. The questionnaire was of a structured undisguised format.

Since the main focus was on determining a decision-maker's predisposition toward customer orientation, an issue that might be considered a socially desirable business value, complete anonymity was explicitly stressed. This would increase the likelihood of evoking true attitudes toward customer satisfaction and its importance. All items in the questionnaire were stated in a 9-point Likert-type format ranging from (1) totally disagree to (9) totally agree. 
The items measuring the commitment and embeddedness constructs were based on the study by Pomerantz et al. (1995). Decision-maker commitment toward the importance of customer satisfaction was measured by four items and three items were used to perationalise the level of embeddedness of this issue. The respondent initiated free response procedure used by Pomerantz et al. (1995) to assess cognitive elaboration could not be used in our survey-based study. Therefore, the four items measuring cognitive elaboration of decision-makers about customer satisfaction were developed specifically for this study. However, the basic ideas of Pomerantz et al. (1995) were left intact. The same holds for the three items operationalising selective judgment, which also had a strong foundation in Pomerantz et al.'s (1995) study. Finally, decision-maker intentions to selectively use customer satisfaction-related intelligence were operationalised by four items based on a study on market intelligence use by Maltz and Kohli (1996). Table 1 presents sample items for each of the constructs.

[Insert Table 1 about here]

\subsection{Construct validation}

Prior to testing the hypotheses we assessed the construct validity of the constructs used in our empirical research. We used structural equation modelling, more in particular confirmatory factor analysis, in LISREL 8 (Jöreskog and Sörbom, 1993) to evaluate unidimensionality, reliability, convergent validity and discriminant validity (Anderson and Gerbing, 1988; Bagozzi, 1980, Bollen, 1989; Gerbing and Anderson, 1988; Kumar and Dillon, 1987; Steenkamp and van Trijp, 1991).

The proposed measurement model with five constructs and eighteen indicators showed an adequate fit to the data: $\chi^{2}(125)=179.76(\mathrm{p}<0.001)$, RMSEA $=0.048$, GFI $=0.87$, AGFI $=$ 
0.82, TLI $=0.95$, CFI $=0.96$ (Bagozzi and Yi, 1988; Bentler, 1990; Bollen, 1989; Hoelter, 1983; Marsh and Hocevar, 1985; Steenkamp and van Trijp, 1991). However, after inspection of the t-values, the pattern of standardised residuals and the modification indices one item for selective intelligence use was deleted (Anderson and Gerbing, 1988; Steenkamp and van Trijp, 1991). Subsequently, we obtained an even better fit: $\chi^{2}(109)=130.31(\mathrm{p}=0.08)$, RMSEA $=0.032, \mathrm{GFI}=0.89, \mathrm{AGFI}=0.85, \mathrm{TLI}=0.98, \mathrm{CFI}=0.98$. Among these the TuckerLewis Index (TLI) (Bentler and Bonett, 1980; Tucker and Lewis, 1973) and the Comparative Fit Index (CFI) (Bentler, 1990) seem to be relatively unaffected by sample size and model complexity (Marsh et al., 1988, 1996). The Root Mean Square Error of Approximation (RMSEA) might provide even a better indication of goodness-of-fit (Steiger, 1990). The value of the RMSEA equals 0.032 and is well below the recommended cut-off value of 0.08 .

Within method-convergent validity was assessed testing the significance and magnitude of the elements of the matrix $\Lambda^{\mathrm{X}}$. All indicator loadings were significant at $\alpha=0.05$ and tvalues ranged from 5.43 to 13.48 . The standardized indicator loadings all exceeded 0.50 ; the average indicator loading is 0.76 for the exogenous constructs (pertaining to commitment and embeddedness) and 0.82 for the endogenous constructs (pertaining to cognitive elaboration, selective judgment, and selective intelligence use). Discriminant validity was evaluated by testing whether pairs of constructs were correlated less than unity. We used a $\Delta \chi^{2}$ with one degree of freedom to test for unity between the constructs. All tests were significant at $\alpha=$ 0.05. Moreover, the reliability of the constructs in the model was evaluated using composite reliability and variance extracted measures (Fornell and Larcker, 1981; Jöreskog 1971). The composite reliability scores ranged from 0.78 to 0.92 . The Cronbach's $\alpha$ reliability coefficients along with construct means, standard deviations, and intercorrelations are presented in table 2 . The reliability scores all exceed the threshold value of 0.70 as proposed 
by Nunnally and Bernstein (1994). After assessing the construct validity we proceed with testing the hypotheses in our hypothesized model.

[Insert Table 2 about here]

\subsection{Hypothesis testing}

The hypothesized model in fig. 1 was tested by estimating the structural model. With the variance-covariance matrix of the indicator variables as input the parameters in the latent variable model were estimated using maximum likelihood estimation (Bentler and Chou, 1987; Bollen, 1989; Hayduk, 1987; Loehlin, 1998). The model shows a satisfactory fit to the data: $\chi^{2}(110)=130.46(\mathrm{p}=0.089), \mathrm{RMSEA}=0.032, \mathrm{GFI}=0.89, \mathrm{AGFI}=0.85, \mathrm{TLI}=0.98$, CFI $=0.98$. Determination of rejection (or failure to reject) is based on the path coefficients (B and $\Gamma$ ) and their supporting statistics (see table 3). The results of the path analysis are also visualized in fig. 2 .

[Insert Table 3 about here]

[Insert Fig. 2 about here]

As can be concluded from table 3 and fig. 2, we fail to reject hypotheses $1,3,4,7$, and 8 at a $5 \%$ significance level. Hypotheses 2, 5, and 6, however, are rejected: none of the respective path coefficients turned out to be significant. More specifically, we found that decision-maker commitment toward customer satisfaction has a relatively strong significant positive effect $\left(\gamma_{1,1}=0.70\right)$ on cognitive elaboration on issues concerning customer satisfaction, such as its 
consequences for the organization. In addition, a direct positive relationship $\left(\gamma_{1,3}=0.44\right)$ between commitment and intentions to selectively use customer satisfaction-related information for making decisions was found: decision-makers highly committed toward satisfying customers are more likely to use attitude-congruent information that, for example, indicates what an organization can do to increase its customers' satisfaction level. However, no significant effect was found for commitment on the selective judgment of customer satisfaction-related information.

For embeddedness of customer satisfaction, the second dimension of attitude strength, we also found a significant positive effect $\left(\gamma_{2,1}=0.18\right)$ on cognitive elaboration on issues concerning customer satisfaction. No relationships were found between attitude embeddedness and selective judgment or intentions to selectively use customer satisfaction-related information. This seems to indicate that embeddedness of customer satisfaction, involving a deeper linkage of the attitude to one's self-concept, value system, and knowledge structure (Pomerantz et al., 1995), indirectly influences decision-maker selective judgment and intentions to act on this attitude through evoking cognitive processes on this matter. On the other hand, commitment toward the importance of satisfying customers directly triggers intentions to selectively use customer satisfaction-related information.

In correspondence with Pomerantz et al. (1995) we also found a strong positive effect $\beta_{1,2}=$ 0.66) of cognitive elaboration on decision-maker selective judgment. In other words, the effect of commitment toward customer satisfaction on selective judgment of satisfactionrelated information is mediated by the level to which one cognitively elaborates on customer satisfaction. Furthermore, it can also be concluded that higher selective judgment of information on customer satisfaction directly contributes to a decision-maker's intention to act in accordance with the attitude and the normative framework used to evaluate the information 
on $\left(\beta_{2,3}=0.30\right)$ : he or she will be more inclined to use information that underlines the importance of customer satisfaction for the organization.

\section{Conclusion}

\subsection{Discussion}

Although not all hypothesized relationships were confirmed, our study indicates that attitude strength is a relevant concept in explaining information use. The results enable the development of a more profound understanding of managerial decision-making processes concerning customer satisfaction and marketing operations in general. The dimensions of attitude strength, commitment and embeddedness, provide key insights into subjective factors creating a bias or non-bias toward customer satisfaction-related information. They explain how a personal prejudice against or favouritism for this issue can lead to the acceptance or rejection of intelligence.

The concept of attitude strength and the results of this study offer an interesting complementary view to previous research, which mainly focused on how instrumental issues, such as the quality of research contents or the presentation of research results influence marketing intelligence use. With this study it becomes clear that these variables represent only one flipside of the coin. Acceptance and use of information is also determined by subjective biases or non-biases following from the strength with which attitudes are being held. Subjectivity can have great influence, no matter how good the quality of the research being conducted or the intelligence provided.

Our results show a sequential flow from the attitude strength commitment dimension to intentions of selectively using customer satisfaction-related information. Commitment, 
focusing on the certainty that one's opinion concerning the importance of customer satisfaction is correct and the extremity of taking a strong position in defending that belief, increases cognitive thinking processes on customer satisfaction-related issues. This might for example be on the positive effects that satisfying customers has for the organization, such as higher sales, higher customer loyalty, and positive word-of-mouth communications. The positive effect of cognitive elaboration on selective judgment indicates that by thinking about customer satisfaction the issue is placed in a cognitive context, to be translated into a normative framework used to judge satisfaction-related information by. Such framework will contain attitude-congruent requirements. This could be that information should underline the importance of satisfying customers by stressing its effect on customer loyalty. In turn, the results indicate that decision-makers who selectively judge customer satisfaction-related information show higher intentions to selectively use information that 'fits' into one's framework. Information for example demonstrating that efforts undertaken to increase customer satisfaction levels indeed lead to a pay-off in terms of extra sales is more likely to be used for decision-making purposes.

In addition to this sequential process, the relevance of commitment toward the importance of customer satisfaction is exemplified by its direct effect on selective intelligence utilization. This seems to indicate that persons who take on a strong standpoint on customer satisfaction and its importance will be more inclined to act accordingly and use information supporting their standpoint. Overall, therefore, it can be concluded that customer satisfaction commitment has a positive impact on the selective acceptance and use of customer satisfaction-related information.

Customer satisfaction embeddedness, referring to one's personal attachment and involvement with customer satisfaction and the belief that the position concerning this issue is reflecting some inner values or concepts, was found to increase cognitive elaboration on customer 
satisfaction. A decision-maker's involvement with customer satisfaction, the personal importance being attached to it, and prior knowledge of customer satisfaction will heighten the level to which one thinks about satisfying customers and what it can do for one's organization. An underlying explanation for the insignificant relationship with selective judgment and intelligence use could be sought in the deeper, internally directed nature of embeddedness. In contrast to attitude commitment, represented as a strong, externally oriented standpoint held by a decision-maker, deeper personal attachment with customer satisfaction is apparently not likely to evoke intentions to act. It first seems to be transferred to a higher level through cognitively thinking about it and these cognitions are then used to develop a normative framework to judge satisfaction-related information by.

\subsection{Theoretical implications}

Since the present study is a preliminary attempt to investigate attitude strength in a marketing decision-making context several theoretical implications need to be taken into account. Acknowledging these implications will be beneficial to marketing intelligence utilization research, but also to research aimed at other marketing-related fields that could benefit from such psychological perspective. An example could be marketing innovation management, in which success rates might depend heavily on the attitudes of the persons involved, e.g. customers and decision-makers.

First, attitude strength research conventionally focuses on quite controversial issues, such as capital punishment, legalized abortion, and environmental preservation (e.g., Pomerantz et al., 1995). Customer satisfaction might not be perceived as particularly controversial. It could even be nominated as a socially desirable value among business practitioners. Consequently, one's attitude toward customer satisfaction and its importance to an organization is not likely 
to elicit such extreme bi-polar reactions as the more social significant and controversial issues are likely to do. As such, a positive-directed tendency in the data might be present. Therefore, future research should also focus on business-related issues likely to elicit more extreme attitudes in both directions, such as the allocation of (marketing) budgets. Decisions then might have a quite varied impact on the parties involved.

Second, customer satisfaction can be interpreted in various ways by different respondents. Future research on the relationship between attitude strength and marketing intelligence use could focus on issues that are more concise. It might for example be interesting to study effects of decision-maker attitudes toward concrete actions that an organization can undertake to increase customer satisfaction levels, such as improving the product offering or increasing service levels. This might lead to more univocal research results, which could further substantiate our conclusions.

Third, as mentioned before, decision-maker attitude strength is only one of many factors that have an impact on the utilization of marketing intelligence. Attitude strength represents a subjective characteristic of information receivers. However, prior research has already proven the impact of instrumental issues of the research project itself (e.g., quality of contents, quality of form, actionability and acceptability of results) on market research intelligence use (Deshpandé and Zaltman, 1982, 1984). We feel that attitude strength should not be seen as a substitute to the explanations offered by these studies; it rather facilitates and complements them. It offers a better understanding of the psychological processes that play a role in managerial decision-making. Therefore, future research should combine the concept of attitude strength with instrumental variables. In doing so, determinants of marketing intelligence use can be studied simultaneously from different perspectives and additional explained variance can be assessed. In addition, the model could also be extended at the front- 
end by including drivers of attitude strength, for example the level of decision-maker experience as suggested by Perkins and Rao (1990).

Next, even though all respondents were working for the same organization and face the same business environment, some variance in the data could be due to situational forces. For example, the functional backgrounds of respondents were varied and future research could investigate whether and, if so, how such functional differences have an impact on attitudes. Another suggestion for future research would be to replicate the study with decision-makers of organizations active in other industries in order to assess generalisability of results.

A final suggestion for future research relates to the research design that we used to study the effects of attitude strength. In this study, a cross-sectional study was conducted by administering questionnaires to decision-makers. The questionnaire contained Likert-type items, all focusing on the importance of satisfying customers, on which respondents could react by self-reporting their level of (dis)agreement with a particular statement. Traditional research on attitude strength, however, is often of a more experimental nature. Subjects then are provided with issue attitude-congruent and -incongruent materials on which they have to react (cf. Pomerantz et al., 1995). Based on these reactions indexes are calculated expressing a tendency to selectively think about the issue or judge information on it. The main advantage of this procedure is that automatic selectivity is assessed more explicitly and according to real-life in which decision-makers are often confronted with information covering 'both sides of the story'. We suggest that future research efforts should adopt such an experimental approach in order to validate the conclusions we draw from our cross-sectional study. This could be done by simultaneously confronting respondents with information stressing the importance of satisfying customers and with information giving counter-arguments concerning this issue. 


\subsection{Managerial implications}

Our results have several interesting managerial implications, both for customer satisfaction or other marketing-related intelligence providers (e.g., marketing research agencies) as well as organizational management. Since attitudes determine acceptance of research information, insight into decision-maker attitudes is important, especially when a study deals with a topic crucial for the organization. Researchers and managers need to recognize that the strength with which attitudes are being held has an impact on cognitive processes, which in turn determine the evaluation and use of issue-related information.

Both attitude commitment and embeddedness play a significant role in the acceptance and use of customer satisfaction-related information. Therefore, decision-maker attitudes should be strengthened by focusing on these dimensions. Researchers conducting customer satisfaction surveys and management should make decision-makers more aware of the importance of satisfying customers for the organization and their own well-being and get them more involved and committed toward the issue. Furthermore, increasing knowledge levels on the benefits of satisfying customers could be achieved by organizing training sessions or publishing periodicals or research reports in which attention is paid to this issue. This will improve the acceptance and use of information obtained by conducting expensive satisfaction surveys.

The results also offer insight into resistance processes against organizational and structural change. Often changes are proposed on the basis of marketing research results that not only affect the position or quality of product and service offerings, but also have major secondary consequences. Strategic changes often require substantive organizational adjustments. To facilitate this transition process senior managers could focus on the strength with which attitudes are being held by organizational members. For example, the outcome of a customer 
satisfaction survey could be that the organization is too product-focused and that the organization lacks customer orientation. For striving for $100 \%$ customer satisfaction massive organizational change at the cultural level is likely to be required. Improving attitudes toward customer satisfaction is likely to lower resistance against measures that need to be taken. Company-wide campaigns could be run to stress the importance of satisfying customers and what the effects will be on the bottom line. Knowledge on the importance for long-term survival and involvement with the issue should be raised, leading to stronger embeddedness of customer orientation into the company. Increasing decision-makers commitment will also facilitate cognitive processes, the selective judgment of satisfaction-related information, and acceptance of information concerning customer satisfaction. 
Fig. 1. Conceptual model of attitude strength

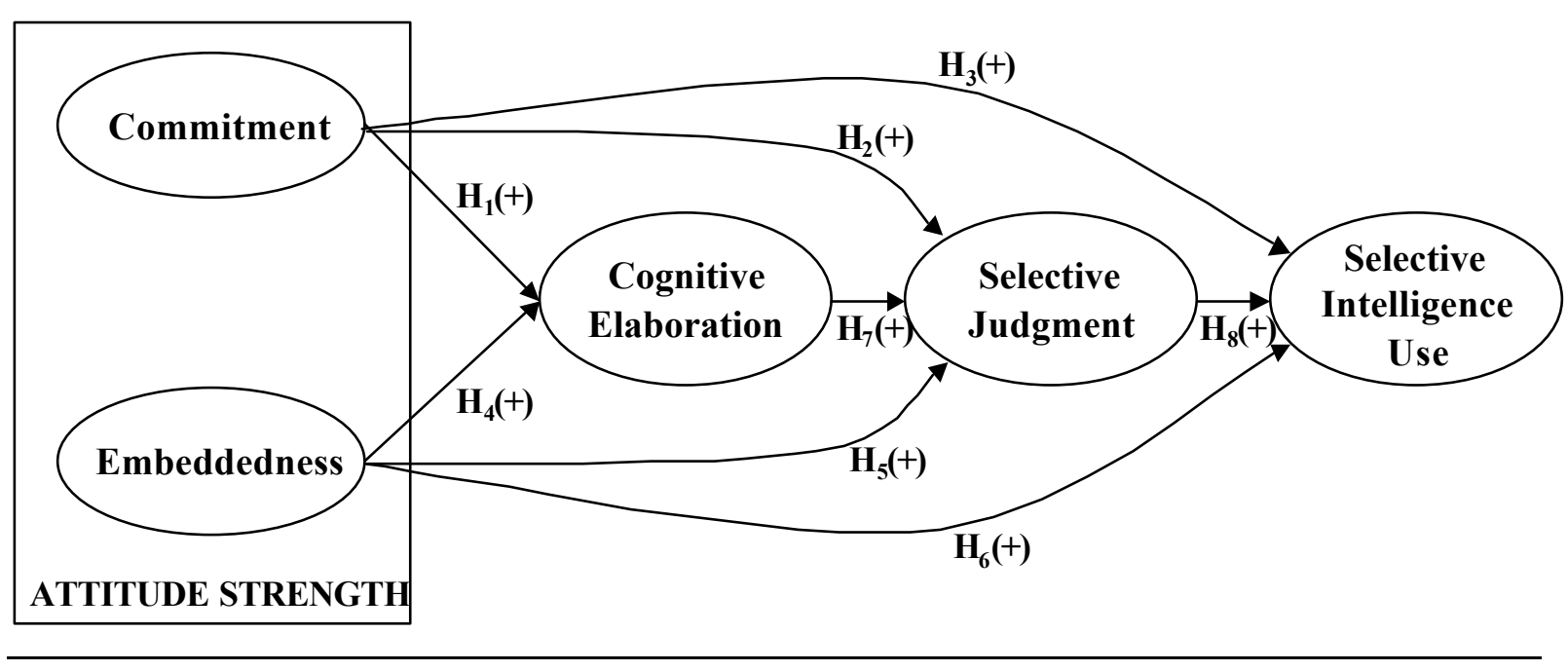


Fig. 2. Causal model of attitude strength ${ }^{\mathrm{a}, \mathrm{b}}$

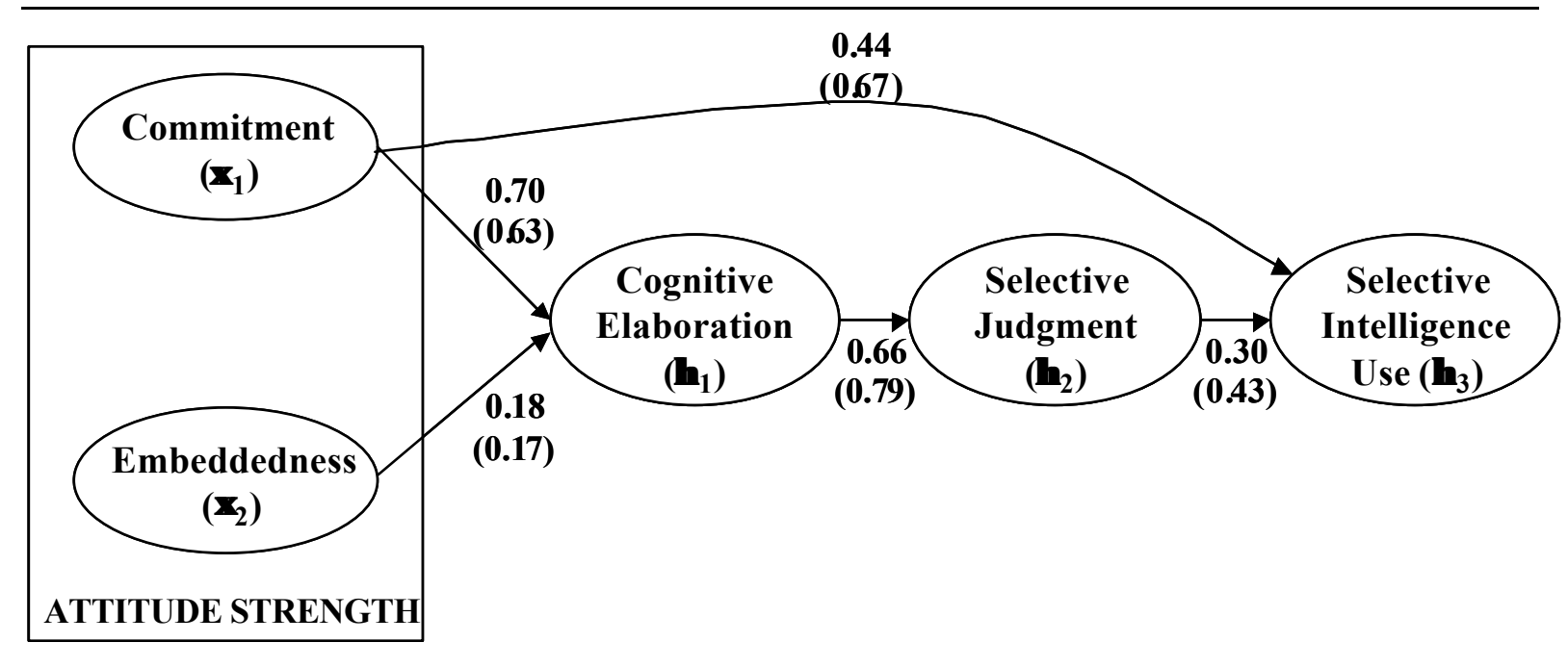

Only significant path coefficients are shown $(\alpha=0.05)$

b Unstandardised path coefficients between parentheses 


\section{Table 1}

Sample items

\begin{tabular}{|c|c|}
\hline Construct & Sample item ${ }^{\mathrm{a}}$ \\
\hline Commitment & $\begin{array}{l}\text { I am convinced that I have a good notion of what after-sales service } \\
\text { elements satisfy our customers } \\
\text { Our customers should be satisfied with our after-sales service at all } \\
\text { times } \\
\text { Striving for satisfaction with our after-sales service should be one of the } \\
\text { top priorities at this company }\end{array}$ \\
\hline Embeddedness & $\begin{array}{l}\text { Satisfying customers through the delivery of quality after-sales service } \\
\text { is a business value with which I associate myself } \\
\text { Personally I find satisfying customers very important } \\
\text { I have a good understanding as to what should happen to prevent our } \\
\text { customer from becoming dissatisfied with our after-sales service }\end{array}$ \\
\hline $\begin{array}{l}\text { Cognitive } \\
\text { Elaboration }\end{array}$ & $\begin{array}{l}\text { I regularly think about how this organization can satisfy customers } \\
\text { through the delivery of value-adding after-sales services. } \\
\text { I often contemplate about the benefits of satisfying our customers } \\
\text { through service excellence (e.g., increased loyalty, positive word-of- } \\
\text { mouth communication, etc.) } \\
\text { When decisions need to be taken concerning the well-being of our } \\
\text { customers, I carefully take my time to think it over }\end{array}$ \\
\hline $\begin{array}{l}\text { Selective } \\
\text { Judgment }\end{array}$ & $\begin{array}{l}\text { Well-conducted satisfaction research should contain detailed } \\
\text { information on critical after-sales service improvement areas } \\
\text { A convincing after-sales service survey should highlight customer } \\
\text { complaints } \\
\text { A convincing after-sales service survey should cover all elements of the } \\
\text { service delivery process }\end{array}$ \\
\hline $\begin{array}{l}\text { Selective } \\
\text { Intelligence Use }\end{array}$ & $\begin{array}{l}\text { Information showing us what can be done to increase customer } \\
\text { satisfaction with our after-sales service helps me to formulate new } \\
\text { service policies } \\
\text { Customer satisfaction information improves my understanding } \\
\text { of how customers perceive our after-sales service quality } \\
\text { I will take concrete actions on the basis of information relating to how } \\
\text { satisfied our customers are with our after-sales services }\end{array}$ \\
\hline
\end{tabular}


Table 2

Means, standard deviations, intercorrelations, and coefficients $\alpha^{\mathrm{a}}$

\begin{tabular}{llccccccc}
\hline Nr. & Construct $^{\mathrm{b}}$ & $\mathbf{M}$ & $\mathbf{S D}$ & $\mathbf{1 .}$ & $\mathbf{2 .}$ & $\mathbf{3 .}$ & $\mathbf{4 .}$ & $\mathbf{5 .}$ \\
\hline $\mathbf{1 .}$ & COMM & 5.56 & 1.45 & $\mathbf{0 . 7 7}$ & & & & \\
2. & EMB & 6.93 & 1.70 & 0.03 & $\mathbf{0 . 8 6}$ & & \\
3. & COGNEL & 5.94 & 1.51 & $0.61^{* *}$ & $0.24^{* *}$ & $\mathbf{0 . 9 4}$ & & \\
4. & SELJUDG & 5.66 & 1.79 & $0.38^{* *}$ & $0.21^{* *}$ & $0.61^{* *}$ & $\mathbf{0 . 8 1}$ & $\mathbf{0 . 8 9}$ \\
$\mathbf{5 .}$ & INTUSE & 4.07 & 1.95 & $0.51^{* *}$ & 0.13 & $0.45^{* *}$ & $0.38^{* *}$ & $\mathbf{0 . 8}$ \\
\hline
\end{tabular}

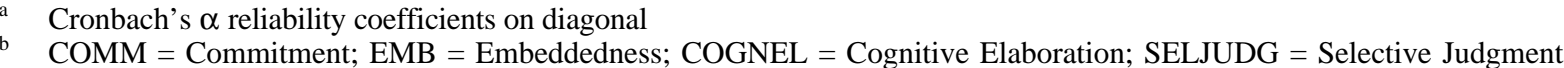
INTUSE $=$ Selective Intelligence Use

Significant at $\alpha=0.05$ (1-tailed)

Significant at $\alpha=0.01$ (1-tailed) 
Table 3

Estimated path coefficients ${ }^{a}$

\begin{tabular}{|c|c|c|c|c|}
\hline Relationships & Hypothesis & $\begin{array}{l}\text { Unstandardised } \\
\text { path coefficient }^{\text {b }}\end{array}$ & $\begin{array}{c}\text { Standardised path } \\
\text { coefficient }\end{array}$ & Hypothesis testing \\
\hline $\mathrm{COMM} \rightarrow \mathrm{COGNEL}$ & $\mathrm{H}_{1}$ & $0.63(6.14)$ & 0.70 & Failed to reject \\
\hline $\mathrm{COMM} \rightarrow$ SELJUDG & $\mathrm{H}_{2}$ & n.s. & n.s. & Rejected \\
\hline COMM $\rightarrow$ INTUSE & $\mathrm{H}_{3}$ & $0.67(3.86)$ & 0.44 & Failed to reject \\
\hline $\mathrm{EMB} \rightarrow \mathrm{COGNEL}$ & $\mathrm{H}_{4}$ & $0.17(2.34)$ & 0.18 & Failed to reject \\
\hline $\mathrm{EMB} \rightarrow$ SELJUDG & $\mathrm{H}_{5}$ & n.s. & n.s. & Rejected \\
\hline $\mathrm{EMB} \rightarrow \mathrm{INTUSE}$ & $\mathrm{H}_{6}$ & n.s. & n.s. & Rejected \\
\hline COGNEL $\rightarrow$ SELJUDG & $\mathrm{H}_{7}$ & $0.79(4.65)$ & 0.66 & Failed to reject \\
\hline SELJUDG $\rightarrow$ INTUSE & $\mathrm{H}_{8}$ & $0.43(2.74)$ & 0.30 & Failed to reject \\
\hline \multicolumn{5}{|c|}{$R^{2} C O G N E L=0.53 ; R^{2}$ SELJUDG $=0.49 ; R^{2}$ INTUSE $=0.42$} \\
\hline \multicolumn{5}{|c|}{$\begin{array}{l}\text { aOMM = Commitment; EMB = Embeddedness; COGNEL = Cognitive Elaboration; SELJUDG = Selective } \\
\text { Judgment; INTUSE = Selective Intelligence Use } \\
\text { b Corresponding t-values between parentheses }\end{array}$} \\
\hline
\end{tabular}




\section{References}

Abelson, R.P., 1988. Conviction. American Psychologists 43, 267-275.

Anderson, E.W., 1996. Customer satisfaction and price tolerance. Marketing Letters 7 (3), 1930.

Anderson, J.C. and D.W. Gerbing, 1988. Structural equation modeling in practice: A review and recommended two-step approach. Psychological Bulletin 103 (1), 411-423.

Bagozzi, R.P., 1980. Performance and satisfaction in an industrial sales force: An examination of their antecedents and simultaneity. Journal of Marketing 44 (Spring), 65-77.

Bagozzi, R.P. and Y. Yi, 1988. On the evaluation of structural equation models. Journal of the Academy of Marketing Science 16 (Spring), 74-94.

Beatty, S.E. and S.M. Smith, 1987. External search effort: An investigation across several product categories. Journal of Consumer Research 14 (1), 83-95.

Bentler, P.M., 1990. Comparative fit indexes in structural models. Psychological Bulletin 61, 238-246.

Bentler, P.M. and D.G. Bonett, 1980. Significance tests and goodness-of-fit in the analysis of covariance structures. Psychological Bulletin 88, 588-606. 
Bentler, P.M. and C. Chou, 1987. Practical issues in structural modeling. Sociological Methods \& Research 16 (August), 78-117.

Bollen, K.A., 1989. Structural equations with latent variables. New York: John Wiley \& Sons.

Chaiken, S., 1980. Heuristic versus systematic information processing and the use of source versus message cues in persuasion. Journal of Personality and Social Psychology 39, 752-766.

Chaiken, S., E.M. Pomerantz, and R. Giner-Sorolla, 1995. 'Structural consistency and attitude strength'. In: R.E. Petty and J.A. Krosnick (eds.), Attitude Strength: Antecedents and Consequences (pp. 387-412). Mahwah, NJ: Lawrence Erlbaum Associates.

Chaiken, S. and S. Yates, 1985. Affective-cognitive consistency and thought-induced attitude polarization. Journal of Personality and Social Psychology 49, 1470-1481.

Davidson, A.R., S. Yantis, M. Norwood, and D.E. Montano, 1985. Amount of information about the attitude object and attitude-behavior consistency. Journal of Personality and Social Psychology 49, 1184-1198.

Deshpandé, R. and G. Zaltman, 1982. Factors affecting the use of market research information: A path analysis. Journal of Marketing Research 19 (February), 14-31.

Deshpandé, R. and G. Zaltman, 1984. A comparison of factors affecting researcher and manager perceptions of market research use. Journal of Marketing Research 21 (February), $32-38$. 
Deshpandé, R. and G. Zaltman, 1987. A comparison of factors affecting use of marketing information in consumer and industrial firms. Journal of Marketing Research 24 (February), $114-118$

Eagly, A.H. and S. Chaiken, 1993. The Psychology of Attitudes. Fort Worth, TX: Harcourt Brace Jovanovich College Publishers.

Eagly, A.H. and S. Chaiken, 1995. 'Attitude strength, attitude structure, and resistance to change'. In: R.E. Petty and J.A. Krosnick (eds.), Attitude Strength: Antecedents and Consequences (pp. 413-432). Mahwah, NJ: Lawrence Erlbaum Associates.

Fishbein, M. and I. Ajzen, I., 1975. Belief, Attitudes, Intention, and Behavior: An Introduction to Theory and Research. MA: Addison-Wesley.

Fiske, S.T. and S.E. Taylor, 1991. Social Cognition. New York: McGraw-Hill.

Fornell, C. and D.F. Larcker, 1981. Evaluating structural equation models with unobservable variables and measurement error. Journal of Marketing Research 18 (February), 19-50.

Gerbing, D.W. and J.C. Anderson, 1988. An updated paradigm for scale development incorporating unidimensionality and its assessment. Journal of Marketing Research 25 (May), 186-192. 
Greenwald, A.G. and C. Leavitt, 1984. Audience involvement in advertising four levels. Journal of Consumer Research 11, 581-592.

Hayduk, L.A., 1987. Structural Equation Modeling with LISREL: Essentials \& Advances. Baltimore \& London: The John Hopkins University Press.

Hoelter, J.W., 1983. The analysis of covariance structures: Goodness-of-fit indices. Sociological Methods and Research 11 (February), 325-344.

Hogarth, R.M. and S. Makridakis, 1988. 'Forecasting and planning: An evolution'. In: P.E. Earl (ed.), Behavioural Economics, Vol. 1, Schools of Thought in Economics Series, No. 6 (pp. 193-216). Aldershot, UK: Elgar/ Brookfield, VT: Gower.

Houston, D.A. and R.H. Fazio, 1989. Biased processing as a function of attitude accessibility: Making objective judgments subjectively. Social Cognition 7, 51-66.

Jaccard, J., 1981. Attitudes and behavior: Implications of attitudes toward behavioral alternatives. Journal of Experimental Social Psychology 17, 286-307.

Jaccard, J. and M.A. Becker, 1985. Attitudes and behavior: An information integration perspective. Journal of Experimental Social Psychology 21, 440-465.

Jaccard, J., C. Radecki, T. Wilson, and P. Dittus, 1995. 'Methods for identifying consequential beliefs: Implications for understanding attitude strength'. In: R.E. Petty and 
J.A. Krosnick (eds.), Attitude Strength: Antecedents and Consequences (pp. 337-359). Mahwah, NJ: Lawrence Erlbaum Associates.

Jöreskog, K.G., 1971. Statistical analysis of sets of congeneric tests. Psychometrika 36 (June), 109-133.

Jöreskog, K.G. and D. Sörbom, 1993. LISREL ${ }^{\circledR}$ 8: Structural Equation Modeling with the SIMPLIS Command Language. Hillsdale: Scientific Software International/Chicago: Lawrence Erlbaum Associates.

Krosnick, J.A., 1988. Attitude importance and attitude change. Journal of Experimental Social Psychology 24, 240-255.

Krosnick, J.A., 1990. American's perceptions of presidential candidates: A test of the projection hypothesis. Journal of Social Issues 46, 159-182.

Krosnick, J.A., D.S. Boninger, Y.C. Chuang, M.K. Berent, and C.G. Carnot, 1993. Attitude strength: One construct or many related constructs? Journal of Personality and Social Psychology 65 (6), 1132-1151.

Krosnick, J.A. and R.E. Petty, 1995. 'Attitude strength: An overview'. In: R.E. Petty and J.A. Krosnick (eds.), Attitude Strength: Antecedents and Consequences (pp. 1-24). Mahwah, NJ: Lawrence Erlbaum Associates. 
Kumar, A. and W.R. Dillon, 1987. The interaction of measurement and structure in simultaneous equation models with unobservable variables. Journal of Marketing Research 24 (February), 98-105.

Lastovika, J.L. and D.M. Gardner, 1979. 'Components of involvement'. In: J.C. Maloney and B. Silverman (eds.), Attitude Research Plays for High Stakes (pp. 53-73). Chicago: American Marketing Association.

Lee, H., F. Acito, and R.L. Day, 1987. Evaluation and use of marketing research by decision makers: A behavioral simulation. Journal of Marketing Research 24 (May), 187-196.

Lee, H., P.M. Herr, F.R. Kardes, and C. Kim, 1999. Motivated search: Effects of choice accountability, issue involvement and prior knowledge on information acquisition and use. Journal of Business Research 45, 75-88.

Lee, H., J.D. Lindquist, F. Acito, 1997. Managers' evaluation of research design and its impact on the use of research: An experimental approach. Journal of Business Research 39, 231-240.

Loehlin, J.C., 1998. Latent Variable Models: An Introduction to Factor, Path, and Structural Analysis. Mahwah, NJ: Lawrence Erlbaum Associates.

Lord, C.G., L. Ross, and M.R. Lepper, 1979. Biased assimilation and attitude polarization: The effects of prior theories on subsequently considered evidence. Journal of Personality and Social Psychology 37, 2098-2109. 
Maheswaran, D. and J. Meyers-Levy, 1990. The influence of message framing and issue involvement. Journal of Marketing Research 27, 361-367.

Maheswaran, D. and B. Sternthal, 1990. The effects of knowledge, motivation, and type of message on ad processing and product judgments. Journal of Consumer Research 17, 66-73.

Maltz, E. and A.K. Kohli, 1996. Market intelligence dissemination across functional boundaries. Journal of Marketing Research 33 (February), 47-61.

Marks, L.J. and M.A. Kamins, 1988. The use of product samples and advertising: Effects of sequences of exposure and degree of advertising claims exaggeration on consumers' beliefs strength, belief confidence, and attitudes. Journal of Marketing Research 25, 266-281.

Marsh, H.W., J.R. Balla, and R.P. McDonald, 1988. Goodness-of-fit indexes in confirmatory factor analysis: The effect of sample size. Psychological Bulletin 103, 391-410.

Marsh, H.W., J.R. Balla, and H.K. Tai, 1996. 'An evaluation of incremental fit indices: A clarification of mathematical and empirical properties'. In: G.A. Marcoulides and R.E. Schumacker (eds), Advanced Structural Equation Modeling: Issues and Techniques. Mahwah, NJ: Lawrence Erlbaum Associates.

Marsh, H.W. and D. Hocevar, 1985. Application of confirmatory factor analysis to the study of self-concept: First- and higher order factor models and their invariance across groups. Psychological Bulletin 97 (3), 562-582. 
Menon, A. and R. Varadarajan, 1992. A model of marketing knowledge use within firms. Journal of Marketing 56 (October), 53-71.

Miller, A.G., J.W. McHoskey, C.M. Bane, and T.G. Dowd, 1993. The attitude polarization phenomenon: Role of response measured attitude extremity, and behavioral consequences of reported attitude change. Journal of Personality and Social Psychology 64, 561-574.

Moorman, Ch., R. Deshpandé, and G. Zaltman, 1993. Factors affecting trust in market research relationships. Journal of Marketing 57 (January), 81-101.

Moorman, Ch., G. Zaltman, and R. Deshpandé, 1992. Relationships between providers and users of market research: The dynamics of trust within and between organizations. Journal of Marketing Research 29 (August), 314-328.

Mulder, P., 1999. 'Er verandert geen moer!': Frustraties met continuklanttevredenheidsonderzoek. Tijdschrift voor Marketing (April), 20-24.

Nunnally, J.C. and I.H. Bernstein, 1994. Psychometric Theory. New York: McGraw-Hill, Inc.

Olson, J.M. and M.P. Zanna, 1993. Attitudes and attitude change. Annual Review of Psychology 44, 117-154.

Perkins, W.S. and R.C. Rao, 1990. The role of experience in information use and decision making by marketing managers. Journal of Marketing Research 27 (February), 1-10. 
Petty, R.E. and J.T. Cacioppo, 1979. Issue involvement can increase or decrease persuasion by enhancing message-relevant cognitive response. Journal of Personality and Social Psychology 37, 1915-1926.

Petty, R.E. and J.T. Cacioppo, 1986a. Communication and Persuasion Central and Peripheral Routes to Attitude Change. New York: Springer-Verlag.

Petty, R.E. and J.T. Cacioppo, 1986b. 'The elaboration likelihood model of persuasion'. In: L. Berkowitz (ed.), Advances in Experimental Social Psychology, Vol. 19 (pp. 123-205). Orlando, FL.

Petty, R.E., J.T. Cacioppo, and D. Schumann, 1983. Central and peripheral routes to advertising effectiveness: The moderating role of involvement. Journal of Consumer Research $10,135-146$.

Pomerantz, E.M., S. Chaiken, and R.S. Tordesillas, 1995. Attitude strength and resistance processes. Journal of Personality and Social Psychology 69 (3), 408-419.

Raden, D., 1985. Strength-related attitude dimensions. Social Psychology Quarterly 48 (4), 312-330.

Raphael, J. and R. Parket, 1991. The need for market research in executive decision making. Journal of Business and Industrial Marketing 6 (1/2) (Winter/Spring), 15-21. 
Rust, R.T., A.J. Zahorik, and T.L. Keiningham, 1995. Return on quality (ROQ): Making service quality financially accountable. Journal of Marketing 59 (April), 58-70.

Sherman, S.J., C.M. Judd, and B. Park, 1989. Social cognition. Annual Review of Psychology 40, 281-326.

Steenkamp, J.B.E.M. and H.C.M. van Trijp, 1991. The use of LISREL $^{\circledR}$ in validating marketing constructs. International Journal of Research in Marketing 8 (4) (November), 283299.

Steiger, J.H., 1990. Structural model evaluation and modification: An interval estimation approach. Multivariate Behavioral Research 25, 173-180.

Tucker, L.R. and C. Lewis, 1973. The reliability coefficient for maximum likelihood factor analysis. Psychometrika, 1-10.

Van der Pligt, J., P. Ester, and J. van der Linden, 1983. Attitude extremity, consensus, and diagnosticity. European Journal of Social Psychology 13, 437-439.

Wetzels, M., K. de Ruyter, and M. van Birgelen, 1998. Marketing service relationships: The role of commitment. Journal of Business and Industrial Marketing 13 (4/5), 406-423.

Wood, W. and C.A. Kallgren, 1988. Communicator attributes and persuasion: Recipients' access to attitude-relevant information in memory. Personality and Social Psychology Bulletin $14,172-182$. 